\title{
China's Fiscal Stimulus and the Recession Australia Never Had: Is a Growth Slowdown Now Inevitable?
}

\author{
Creina Day ${ }^{1}$
}

\section{Abstract}

China's timely and well-targeted two-year fiscal stimulus was particularly effective in stimulating growth in Australia's commodity exports. Using a constructed series of export volumes to China, this paper finds that the post-stimulus GDP growth contribution from export volumes to China is significant. Had growth in export volumes to China been commensurate with pre-stimulus rates, Australia would have experienced three consecutive quarters of negative real GDP growth - a technical recession. China's gradual and uniquely revenue-based unwinding of fiscal stimulus reduces the risk to Australia of an imminent growth slowdown.

\section{Introduction}

One of the defining features of the Great Recession was the 'sudden, severe and synchronized' collapse in world trade for the December 2008 and March 2009 quarters (Baldwin 2009). But just as small open economies, such as Australia, were vulnerable to the economic wellbeing of their trading partners, they also especially benefited from the fiscal stimulus implemented simultaneously worldwide.

This paper explores how, and to what extent, Australia benefited from the fiscal stimulus of its most important trading partner, China, and whether we may expect to witness a slowdown in growth as the unwinding of global fiscal stimulus begins in earnest in 2011.

Australia distinguished itself from other advanced economies by escaping a technical recession, defined as two quarters of negative growth in real GDP. The consensus that Australia experienced a slowdown but avoided a recession rests on the positive real GDP growth result for the March 2009 quarter.

1 The Crawford School of Economics and Government, the Australian National University; creina.day@anu. edu.au The author thanks the editor, William Coleman, and a referee for constructive comments. 
The existing literature analyses the effectiveness of the Australian government's package of cash transfers and infrastructure investment in countering a recession. Leigh (2009) finds cash bonuses were particularly effective in stimulating consumption. Lim et al. (2010) suggest cash for consumption was more effective in stimulating consumer confidence and that the effect of infrastructure investment, largely introduced at the bottom of the slowdown, is most likely delayed.

On the other hand, Makin (2010) finds that net exports, not Australia's fiscal stimulus, was primarily responsible for offsetting a fall in private investment due to the Global Financial Crisis (GFC). For the March 2009 quarter, the net positive contributions of private and public consumption totalling 0.3 per cent were minor in relation to the contribution from net exports of 2.0 per cent.

This paper builds on this growth analysis, which tells us how broad category GDP components changed, by exploring why exports rose both during and since the fiscal stimulus. It hypothesises that the rise in exports is in fact due, in part, to fiscal stimulus - that of the Chinese government. Of course, a rise in net exports can be due to a fall in imports, reflecting weakening domestic demand. Consistent with the global contraction in trade (IMF 2010a), for the December 2008 quarter both Australian exports and imports fell by 1.4 and 8.3 per cent, respectively, over the previous quarter. However, in the March 2009 quarter, Australia broke from the pack with modest growth in exports of 1.6 per cent over the previous quarter. Since then, exports have contributed positively to real GDP growth in five out of seven quarters.

This paper adds to the existing literature on fiscal stimulus by examining two key questions that have been overlooked. Firstly, how much did growth in export volumes to China contribute to real GDP growth in Australia? Secondly, how will the unwinding of China's fiscal stimulus affect Australia's real GDP growth in the coming decade?

To address the first question, this paper constructs a quarterly data series, March 2000 to September 2010, of export volumes to China, which it then uses to calculate the real GDP growth contribution from the growth in export volumes to China. The quarterly growth contribution series allows us to investigate the counterfactual: had the growth contribution remained at the average prestimulus level, would Australia have experienced a recession?

To address the second question, the general budget balances of China are compared with those of other major economies. There is an explanation of why China's planned composition of fiscal adjustment is unique and the implications of this for the Australian economy are discussed. 


\section{China's Stimulus to Infrastructure Investment}

China was able to implement one of the largest and most timely fiscal stimulus packages (IMF 2010a). Natural growth in tax revenue ${ }^{2}$ provided China with fiscal ammunition unavailable to OECD countries. Accordingly, China's fiscal package constituted a reallocation of spending to infrastructure rather than burgeoning debt. ${ }^{3}$ Policymakers pragmatically decided to accelerate already approved infrastructure projects. By shortening five-year implementation to two years, projects were able to get off the ground fast. A large part of the stimulus spending was diverted to building strategic stockpiles of raw materials.

Figure 1: China's growth in fixed-asset investment (percentage change, year on year)

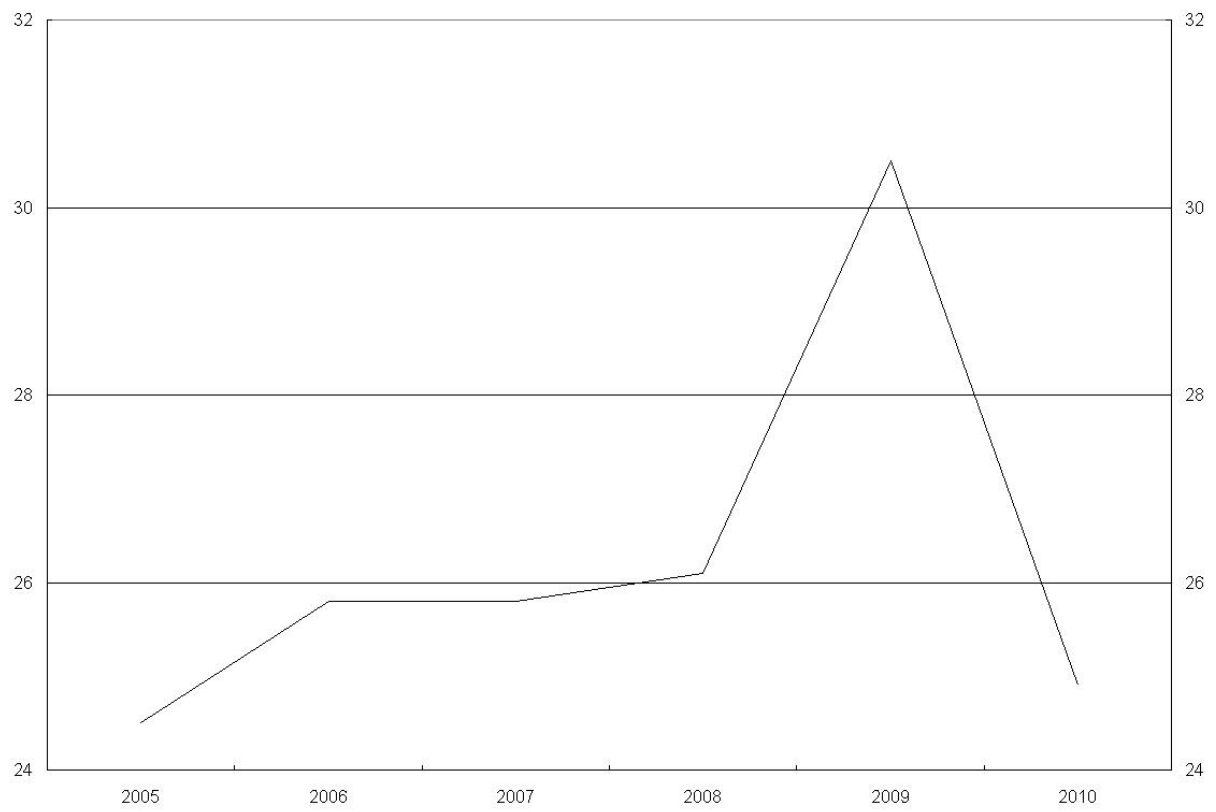

Source: National Bureau of Statistics of China, Investment in Fixed Assets

As shown in Figure 1, growth in investment temporarily spiked in 2009 as a result of fiscal stimulus measures. ${ }^{4}$ China's investment in fixed assets totalled 22.48 trillion RMB in 2009, up 30.1 per cent year on year. Since the mid-1990s the share of infrastructure investment was declining while manufacturing gained share. Fiscal stimulus reversed this trend sharply in 2009.

2 The development of China's tax system, primarily a consequence of urbanisation, has been sufficient to ensure that increases in tax revenue have accompanied surges in GDP growth (Tyers and Huang 2009).

3 In 2009, China's fiscal deficit, as a percentage of GDP, was less than a third of the average of advanced G20 economies (IMF 2010b).

4 Government fixed-asset investment was up 60 per cent year on year in 2009 (World Bank 2010). 
A priori, we would expect China's fiscal stimulus to be especially effective in stimulating domestic economic activity for two reasons. Firstly, government investment directly affects aggregate demand, whereas government transfers and tax cuts stimulate household consumption via disposable income (see Gali et al. 2007). Secondly, since the Chinese currency is effectively pegged to the US dollar, China eases monetary policy in line with the United States. Domestic demand increases relatively more because of the low real interest rate. This is consistent with the Mundell-Fleming model, one of the workhorses of openeconomy macroeconomics, which predicts that fiscal policy is more effective in stimulating domestic output under pegged, rather than floating, exchange rates.

We would also expect fiscal stimulus in such a large and relatively open economy to have significant international spillovers. Consistent with the Keynesian view of the world, a fraction of the fiscal expansion is diverted to the rest of the world through higher imports.

Recent estimates of multiplier effects, based on ex-ante simulations, support this a priori reasoning. For emerging Asia, Freedman et al. (2010) estimate that the fiscal multiplier of a two-year stimulus is 2.0 and 0.7 on domestic and world GDP, respectively. For the US, the simulated effects on domestic and world GDP are almost half this magnitude. The emerging Asia two-year multiplier is consistent with a one-year multiplier for China of 0.84 (He et al. 2009).

Since a significantly larger share of imported mining products is used in construction than is used in manufacturing, ${ }^{5}$ we would expect the Chinese government's spending on infrastructure to generate spillovers for major exporters of iron ore and coal, in particular. Cova et al. (2010) predict that China's fiscal stimulus will raise exports from Japan and the rest of the world (including Australia) by four times the rise in exports from the US and euro area.

The significance of these spillovers to Australia is reflected in Figure 2. In 2009, both China and Australia recorded positive but slowing growth. In 2010, real GDP growth rose by $1 \frac{1}{4}$ and $1 \frac{3}{4}$ percentage points in China and Australia, respectively.

5 Construction uses around 5 per cent of minerals supplied domestically, compared with 35 per cent for manufacturing (National Bureau of Statistics of China). 
Figure 2: Annual real GDP growth (percentage change, year on year)

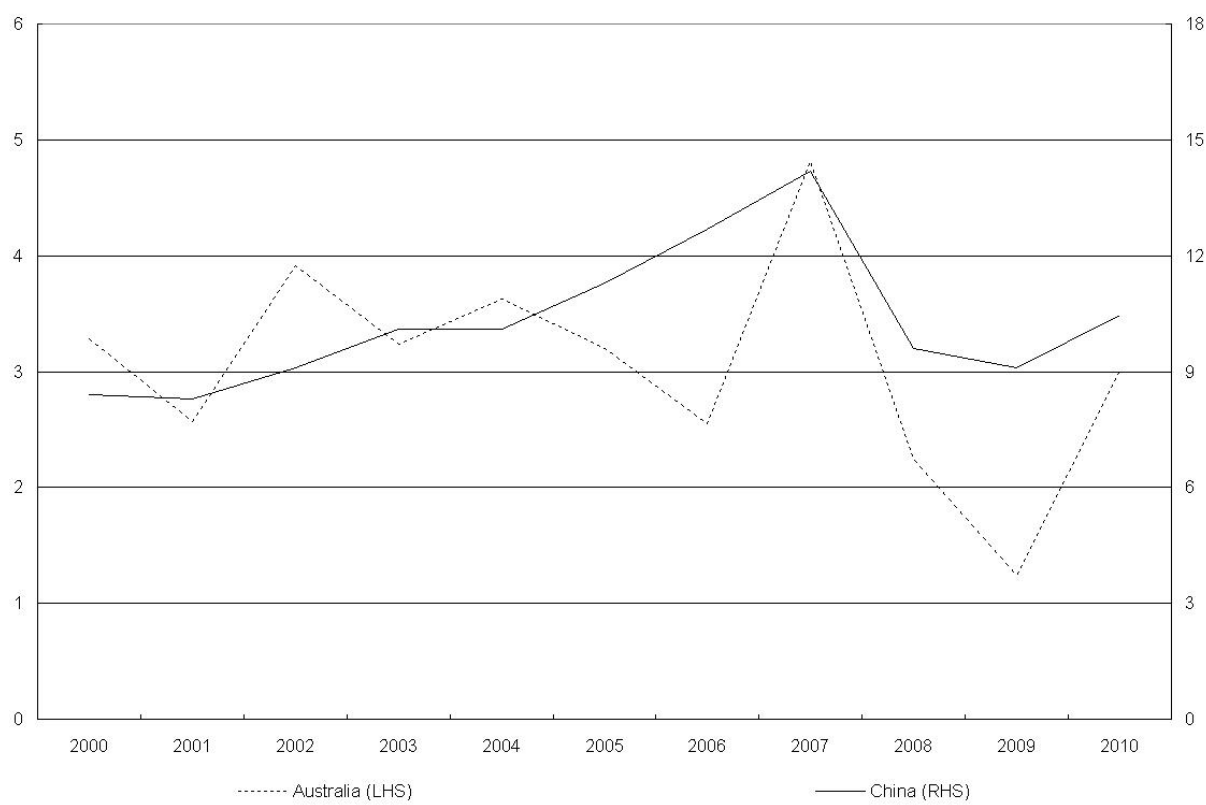

Source: ABS, Australian National Accounts, Catalogue 5206.0; National Bureau of Statistics of China; IMF

To sum up, the Chinese government's spending on infrastructure had:

- a larger effect on both China's GDP and the rest of the world than any other G20 economy

- significant international spillovers via demand for exports, especially from Australia.

\section{Did Increased Exports to China Avert a Recession?}

To quantify the extent to which China's increased demand for exports averted a technical recession in Australia, we need to:

- estimate the volume of merchandise exports to China; and

- isolate the contribution to growth in real GDP for each quarter.

On account of the significant changes in commodity prices over the critical 'recession we never had' period, changes in the total value of merchandise exports to China will mask changes in demand. In Australian dollar terms, 
commodity prices peaked in October 2008, falling by around 43 per cent through to October 2009. By January 2011, commodity prices were up 45 per cent from their low, but remained 18 per cent lower than their peak (RBA 2010).

So, to derive a series of export volumes to China, the total value of merchandise exports to China is deflated by the RBA Index of Commodity Prices (ICP) reflected in Australian dollars. ${ }^{6}$ Specifically, the monthly volume of merchandise exports to China for the period January 1988 to September 2010 is derived as:

Real (Volume of) Merchandise Exports to China $\approx$

Merchandise Exports to China $\div$ Index of Commodity Prices

which is then seasonally adjusted, using the X12 method. ${ }^{7}$ The monthly series is converted, to allow comparison with quarterly real GDP data.

\section{Figure 3: Growth in real GDP and export volumes to China (per cent)}

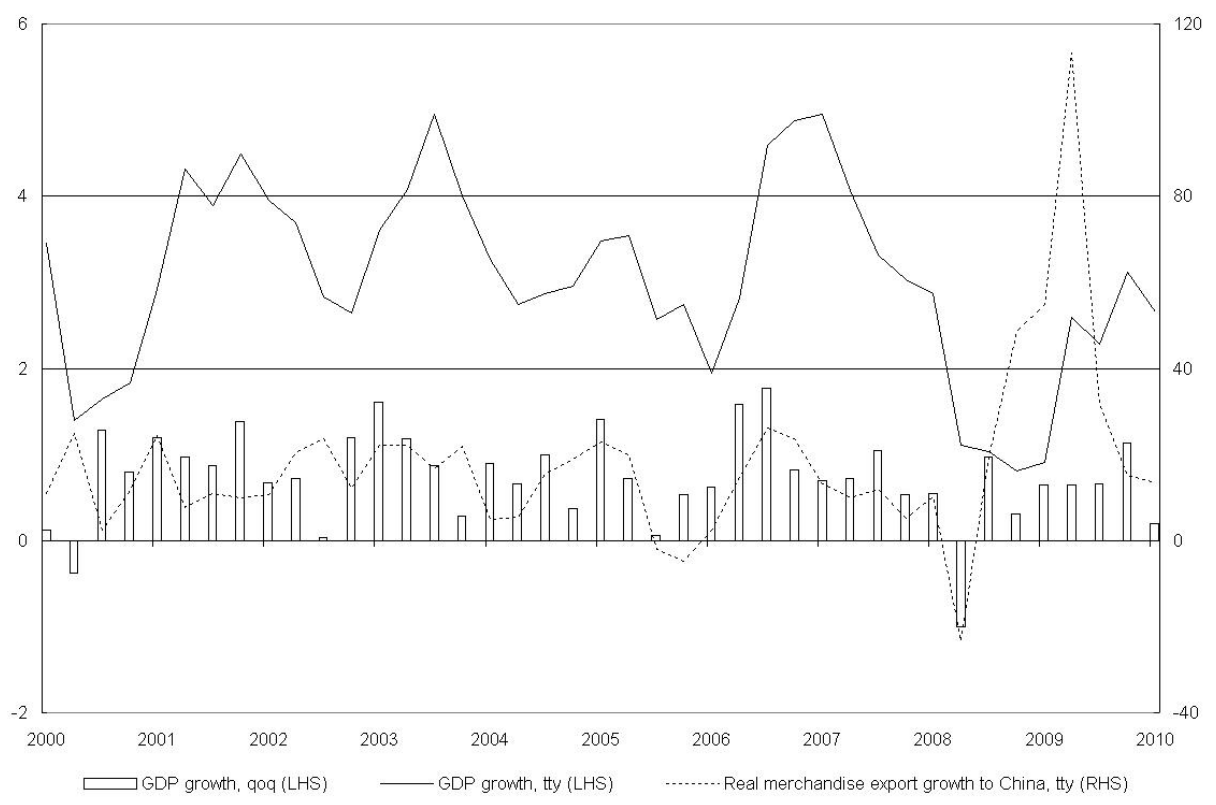

Source: ABS Cat. No. 5206.0, ABS Cat. No. 5368.0, RBA, and author's calculations

6 The weights assigned to each commodity in the ICP reflect both the share of export volumes in 2008-09 and the impact of subsequent price changes on export values. Reflective of Australian exports to China, mining commodities comprise almost 90 per cent of the index (RBA 2009). In particular, the ICP weights for metallurgical coal and iron ore closely reflect exports to China. In the absence of an official series of export volumes, by major trading partners, deflating export values by the ICP therefore provides a reasonably accurate measure of export volumes to China.

7 This method is undertaken using Eviews. 
Figure 3 reveals that since the global fiscal stimulus, growth in the volume of exports to China leads real GDP growth in Australia on a through-the-year basis. The question of averted recession relates to real GDP growth in each quarter (the bars in Figure 3). Thus, we wish to isolate the growth contribution from export volumes to China in each quarter.

We start with a decomposition of real GDP into expenditure components. With some algebraic manipulation, we obtain the growth contribution from each expenditure component. Specifically, the real GDP growth contribution from exports to China, for quarter $t$, is derived as:

(Volume of Merchandise Exports to China $\div$ Real Australian GDP, $t-1) \times$ Growth in Volume of Merchandise Exports to China, $t$

\section{$=$ Contribution to Growth in Real Australian GDP, $t$}

With reference to Figure 3, prior to the global financial crisis and fiscal stimulus, the growth contribution from exports to China is negligible, averaging less than one-tenth of one percentage point. However, there is a significant negative growth contribution in the December 2008 quarter, followed by a positive spike in the March 2009 quarter.

If Australia had continued to export to China, but without such anomalous growth in exports, we would have experienced three consecutive quarters of negative growth in real GDP (see dashed line in Figure 4).

\section{Figure 4: Real GDP growth contribution of export volumes to China (per cent)}

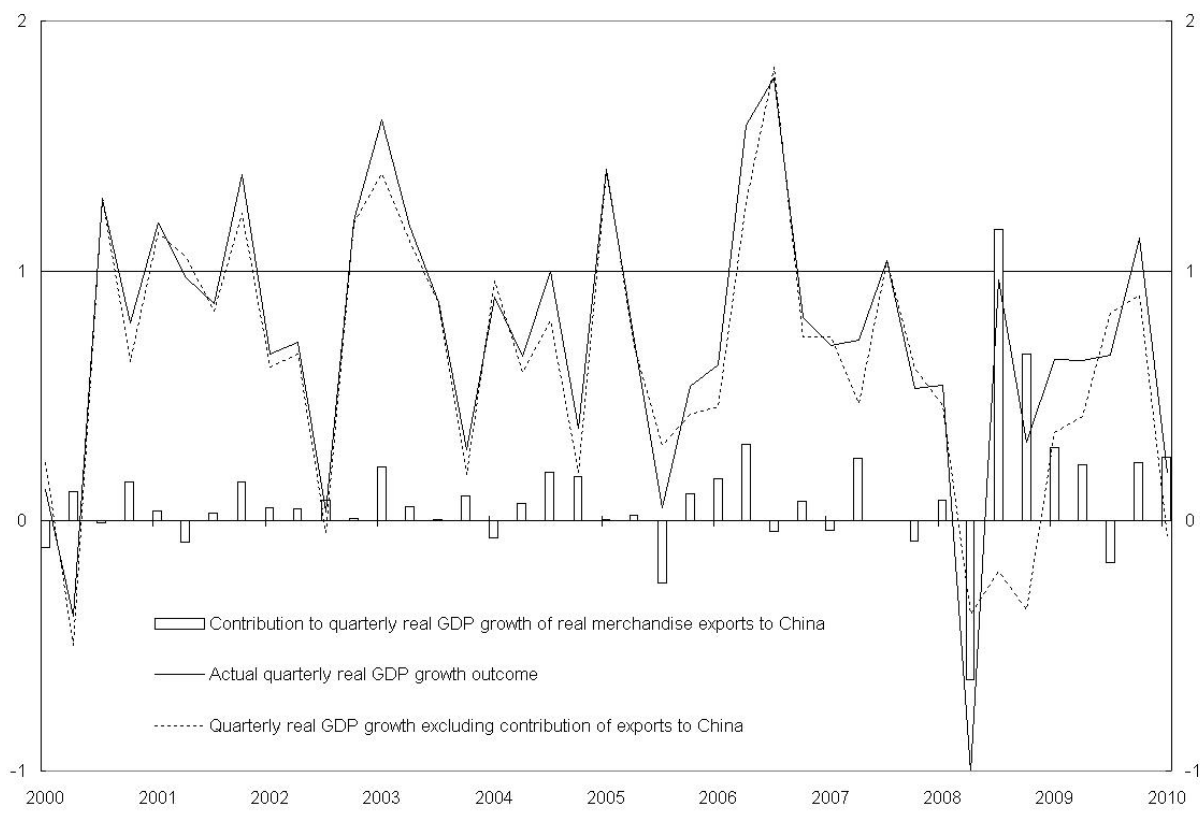


In Table 1, the first four columns summarise the key series, depicted in Figures 3 and 4, for the critical period September 2008-September 2009. We now consider the counterfactual: if real exports to China had grown at the average pre-stimulus rate, would Australia have experienced two quarters of negative real GDP growth? The average pre-stimulus rate is taken from 2003-04, which marks the beginning of the commodities boom.

Table 1: Contribution to real GDP(E) growth (percentage change, quarterly)

\begin{tabular}{llllll}
\hline & $\begin{array}{l}\text { Real } \\
\text { GDP } \\
\text { Growth }\end{array}$ & $\begin{array}{l}\text { Growth } \\
\text { in Export } \\
\text { Volumes } \\
\text { to China }\end{array}$ & $\begin{array}{l}\text { Growth } \\
\text { Contribution } \\
\text { from Exports } \\
\text { to China }\end{array}$ & $\begin{array}{l}\text { Real GDP Growth } \\
\text { excl. Growth } \\
\text { Contrib. from } \\
\text { Exports to China }\end{array}$ & $\begin{array}{l}\text { Real GDP Growth } \\
\text { if Growth Contrib. } \\
\text { at average rate } \\
\text { Sep03-Jun08 }\end{array}$ \\
(i) & (ii) & (iii) & (i) - (iii) $=$ (iv) & $\begin{array}{l}\text { (iv) }+0.065= \\
\text { (v) }\end{array}$ \\
Sep - 2008 & 0.54 & 3.14 & 0.08 & 0.46 & 0.53 \\
Dec - 2008 & -1.00 & -23.46 & -0.63 & -0.37 & -0.31 \\
Mar - 2009 & 0.97 & 55.85 & 1.17 & -0.20 & -0.14 \\
Jun - 2009 & 0.31 & 20.72 & 0.67 & -0.35 & -0.29 \\
Sep - 2009 & 0.65 & 7.56 & 0.29 & 0.35 & 0.42 \\
\hline
\end{tabular}

Source: ABS Catalogue 5206.0; ABS Catalogue 5368.0; RBA; author's calculations

The final column of Table 1 reveals that, had export volumes to China grown at the average pre-stimulus rate, Australia would have experienced a technical recession. Three quarters of negative growth under the counterfactual scenario is comparable with the actual experience of most advanced economies.

\section{Will the Unwinding of Stimulus Slow Growth?}

The preceding section's analysis of the recent past raises questions about the near future. The world economy grew by around 5 per cent in 2010. With the return of buoyant global economic activity, the unwinding of fiscal stimulus is expected to gather momentum in 2011. Figure 5 shows, on the one hand, the structural shift of growing exports to China, commencing 2003-04, and on the other hand, the post-stimulus spike in 2009. Should Australia be concerned that some of the gains from growth in export volumes to China, quantified in this paper, will be reversed in the years ahead? 
Figure 5: Australian exports to China as a proportion of GDP (per cent)

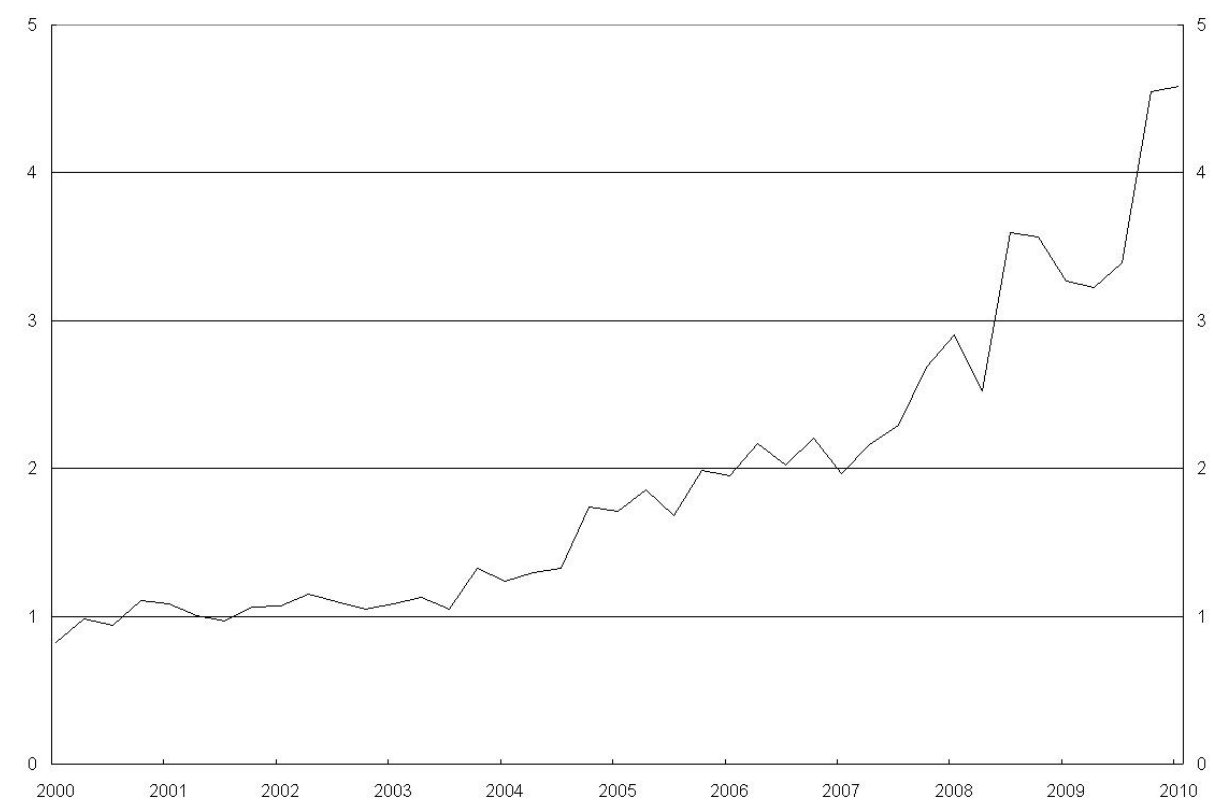

Source: ABS Catalogue 5206.0; ABS Catalogue 5368.0

China ran a budget deficit of around 3 per cent of GDP in 2009, around 2.7 per cent higher than the previous year. While the Chinese authorities held their budget deficit broadly unchanged in 2010, they are expected to reduce it by around 1 per cent of GDP in 2011. Having said this, as shown in Table 2, China has a relatively low deficit (below 5 per cent of GDP). Accordingly, whilst the government has not published medium-term targets, it has voiced a preference for a relatively gradual adjustment in the overall budget balance (IMF 2010b).

Table 2: General government budget balance (percentage of GDP)

\begin{tabular}{lllll}
\hline Country & 2009 & 2010 & 2011 & 2012 \\
\hline China & -3.1 & -3.1 & -2.1 & -1.5 \\
United States & -12.7 & -10.6 & -10.8 & -7.2 \\
Japan & -10.1 & -9.4 & -9.1 & -8.0 \\
United Kingdom & -10.3 & -10.3 & -8.1 & -6.1 \\
\hline
\end{tabular}

Source: IMF Fiscal Monitor Update, 2011

China is unique in that, unlike other countries, budgetary improvements are likely to come largely from the revenue side, given the potential for high revenue growth. Therefore, the risk to growth in Australia's export volumes to 
China lies in the unwinding of government infrastructure spending. Growth in government-influenced fixed-asset investment has decelerated from the high base in 2009. However, the phasing out of active government construction projects will take years, and infrastructure spending on low-income housing projects has been recently announced (Ministry of Finance 2011).

Urbanisation, which underpins growth in not only tax revenue but also construction, is estimated to increase from 47.5 per cent to 51.5 per cent in the next five years (Wen 2011). In 2010, both strong real-estate investment growth and fast recovery in China's export volumes, reflecting improved global demand, partly offset any slowdown in government-led demand for mineral imports from Australia (World Bank 2010).

On the one hand, the gradual unwinding of China's government-led investment, strong real-estate investment and recovery in export volumes is good news for Australia. On the other hand, domestic demand is beginning to slow (World Bank 2010), suggesting the current pace of import growth may not last.

\section{Conclusion}

Australia enjoyed a double bonus during the global financial crisis: the first came from its own fiscal stimulus; the second from the public infrastructure spending of its major trading partner, China, reflected in increased exports. Given the timely implementation of infrastructure projects and a pegged exchange rate, China's fiscal stimulus was particularly effective in stimulating demand for commodity exports from Australia.

Using a constructed quarterly series of export volumes to China, we find that since the global fiscal stimulus, growth in export volumes to China leads growth in Australia's real GDP. The real GDP growth contribution from export volumes to China spiked in the March and June quarters 2009. Had export volumes to China grown at the pre-stimulus rate, Australia would have experienced three consecutive quarters of negative real GDP growth.

Whilst growth in export volumes to China contributed significantly, especially to the positive real GDP growth result for the March quarter 2009, there is no denying the importance of other factors contributing to Australia's real GDP growth. Rather, the post-stimulus real GDP growth contribution from growth in export volumes to China is a previously unidentified magnitude that is worth considering in light of both the recession Australia never had and the imminent unwinding of global fiscal stimulus. Fortunately for Australia, China's unwinding of fiscal stimulus is likely to be gradual and uniquely revenue-based. 


\section{References}

Australian Bureau of Statistics 2010, International Trade in Goods and Services, Catalogue 5368.0, Australian Bureau of Statistics, Canberra.

Australian Bureau of Statistics 2010, Australian National Accounts: National Income, Expenditure and Product, Catalogue 5206.0, Australian Bureau of Statistics, Canberra.

Cova, P., Pisano, M. and Rebucci, A. 2010, Macroeconomic Effects of China's Fiscal Stimulus, Inter-American Development Bank (IDB) Working Paper Series 211, September, IDB.

Baldwin, R. (ed.) 2009, The Great Trade Collapse: Causes, Consequences and Prospects, A VoxEU.org Publication, Geneva.

Freedman, C., Kumhof, M., Laxton, D., Muir, D. and Mursula, S. 2010, 'Global Effects of Fiscal Stimulus During the Crisis', Journal of Monetary Economics 57: 506-26.

Gali, J., Lopez-Salido, J. and Valles, J. 2007, 'Understanding the Effects of Government Spending on Consumption', Journal of the European Economic Association 5(1): 227-70.

He, D., Zhang, Z. and Zhang, W. 2009, How Large Will Be the Effect of China's Fiscal-Stimulus Package on Output and Employment? Hong Kong Monetary Authority (HKMA) Working Paper 05/2009, March, Hong Kong.

International Monetary Fund 2010a, Navigating the Fiscal Challenges Ahead, IMF Fiscal Monitor, May, IMF, Washington DC.

International Monetary Fund 2010b, Fiscal Exit: From Strategy to Implementation, IMF Fiscal Monitor, November, IMF, Washington DC.

International Monetary Fund 2011, Strengthening Fiscal Credibility, IMF Fiscal Monitor Update, January, IMF, Washington DC.

Leigh, A. 2009, How Much Did the 2009 Fiscal Stimulus Boost Spending? Evidence from a Household Survey, CAMA Working Paper Series 22/2009, The Australian National University.

Lim, G., Chua, C. L., Claus, E. and Tsiaplias, S. 2010, 'Review of the Australian Economy 2009-2010: On the Road to Recovery', The Australian Economic Review 43(1): 1-11.

Makin, A. 2010, 'Did Australia's Fiscal Stimulus Counter Recession?: Evidence from the National Accounts', Agenda 17(2): 5-16. 
Ministry of Finance 2011, Report on the Implementation of the Central and Local Budgets for 2010 and on the Draft Central and Local Budgets for 2011, March, Ministry of Finance, China.

National Bureau of Statistics of China 2010, Statistical Data. Available at: http:// www.stats.gov.cn/english/statisticaldata/

Reserve Bank of Australia 2009, 'Updating the RBA's Index of Commodity Prices', Reserve Bank Bulletin, October, RBA.

Reserve Bank of Australia 2010, Statistical Tables. Available at: http://www.rba. gov.au/ statistics/index.html

Tyers, R. and Huang, L. 2009, Combating China's Export Contraction: Fiscal Expansion or Accelerated Industrial Reform? CAMA Working Paper Series 22/2009, The Australian National University.

Wen, J. 2011, Report on the Work of the Government, Fourth Session of the Eleventh National People's Congress, delivered 5 March. Available at: http:// news.xinhuanet.com/english2010/china/2011-03/15/c_13779521.htm

World Bank 2010, China Quarterly Update, June, World Bank. 